\title{
CHARCOAL IN ALLUVIUM OF MOUNTAIN STREAMS IN THE BIESZCZADY MOUNTAINS (POLISH CARPATHIANS) AS A CARRIER OF INFORMATION ON THE LOCAL PALAEOENVIRONMENT
}

\author{
JÓZEF KUKULAK \\ Institute of Geography, Pedagogical University, 2 Podchorażych Str., 30-084 Cracow, Poland
}

Received 2 September 2013

Accepted 20 January 2014

\begin{abstract}
Fragments of charcoal are present in floodplain alluvium of the San and Strwiąż rivers in the Polish part of the Bieszczady Mountains, Polish East Carpathians. They occur as single clasts or in lenses in the basal part of fine-grained alluvium, together with unburnt wood debris, or in the middle part of the vertical sequence of the floodplain alluvium. 14 samples of charcoal from the upper courses of the San $(c a .50 \mathrm{~km})$ and the Strwiąż $(c a .10 \mathrm{~km})$ were dated with radiocarbon. The obtained dates fall mainly in the $15^{\text {th }}$ through $19^{\text {th }}$ century interval; only one sample is markedly older $\left(9^{\text {th }}-10^{\text {th }}\right.$ century). Taxonomic composition of the charcoal source wood was also studied and compared with that of coeval forests. Correlation of the charcoal age with the history of economic development of the studied region indicates that charcoal is of anthropogenic origin: older charcoal from intense slash-and-burn deforestation, while younger charcoal was produced by local industries.
\end{abstract}

Keywords: charcoal, alluvium, slash-and-burn agriculture, Bieszczady Mountains.

\section{INTRODUCTION}

Charcoal is one of components of debris left by fires which involved wood. Its origin is related to intentional and controlled sources of fire (household and industrial ovens, bonfires) as well as to spontaneously originated and uncontrolled fires, usually resulting in damages (natural fires in forests or buildings). The origin of charcoal has no influence on the mode of its fluvial transport and deposition; charcoal is subject to the same processes as accompanying mineral components (Knox, 1987; Wójcicki and Marynowski, 2011).

Fire debris originated from wood usually comprises fragments of charred trunks, branches and roots, and their derivatives (bark, bracket fungi, cones, seeds, resin), charcoal dust and ash from trees, brushes and grasses.

Corresponding author: J. Kukulak

e-mail: jkukulak@up.krakow.pl
Mineral components of fire debris include baked clay (from burned forests or meadows, from clay daub on ovens or cellar walls), as well as ceramic, glassy or metallic sinters. Each of these materials may eventually become a component of alluvium, as it may be washed to a fluvial channel or may be discarded by humans as waste.

Charcoal is usually a subordinate component of alluvium, present in minute amounts among the mineral components, seldom as more than $1 \%$ of their volume. The presence of charcoal along the courses of the Carpathian rivers is observed only in fine-grained alluvium (sand, mud or clay) of the youngest terraces. Moreover, subfossil charcoal is present in these sediments only locally. It is difficult to recognize with a naked eye because individual particles are usually fine and dispersed among mineral grains; only rarely they form distinct concentrations. The finest charcoal grains (charcoal dust) are discernible under microscope only. 
Subfossil charcoal, despite of its trace amounts in sediments, is a valuable carrier of information on palaeoenvironment of a drainage basin, especially on the origin, transport and deposition of charcoal itself. It may prove the past presence of intense burning of natural fires or burning of wood by humans (Tipping and Milburn, 2000; Scott, 2010). Natural forest fires were rather infrequent in the Carpathians during the last millennium and they had local extent (Szewczuk, 1939), while those resulting from more or less controlled human activity could be much more frequent (Strzelecki, 1900; Kubijowicz, 1926; Broda, 1952; Łowmiański, 1953). The presence of charcoal makes dating the fires possible by radiocarbon dating or other methods.

Subfossil charcoal is present, among others, in alluvia of the Carpathian rivers. This paper documents the presence of such charcoal in the Bieszczady Mountains in Polish Carpathians (drainage basins of the upper San and Striąż rivers). It includes description of the position of charcoal in vertical sections of alluvia, their mesoscopic characteristics, taxonomic composition and the results of their radiocarbon dating. Temporal and causal relationships between their accumulation and the history of regional economic developments is outlined. The study was limited to the Bieszczady parts of the San and Strwiąż drainage basins, but its results seem to apply to a wider area. It is likely that the sources of charcoal in other mountain areas were similar.

\section{REVIEW OF LITERATURE ON CHARCOAL}

Subfossil charcoal was little studied by Polish geologists and geomorphologists. Its presence in alluvia is only occasionally mentioned and its origin in regions other than the Góry Świętokrzyskie (Klatka, 1968; Kosmowska-Sufczyńska, 1983) and the basin of the upper Odra and Nysa Kłodzka rivers (Klimek, 1999; Latocha, 2007; Wójcicki and Marynowski, 2011) has been not clearly explained (Dumanowski et al., 1962, Teisseyre, 1989; Kalicki and Krąpiec, 1991; Bieroński et al., 1992; Gębica and Krapiec, 2009). It was not studied in detail and its presence is accepted (hypothetically) as the record of recent human activity. Charcoal in alluvia of Scandinavian rivers is accepted as a firm proof of regular use of fire in human management of land since Mesolithic times (Simmons, 1978; Chandler et al., 1983; Göransson, 1987; Innes and Simmons, 2000; Kasin et al., 2013). Also in Great Britain the presence of charcoal in sediments of rivers, lakes and peat bogs is interpreted as the record of ancient forest clearing by the use of fire, of primitive agriculture and settlement (Simmons and Innes, 1996; Moore, 2000; Mason, 2000).

The presence of small fragments of charcoal was noted by palynologists in sections of some peat bogs (Szczepanek, 1987; Ralska-Jasiewiczowa, 1989; Kalinowicz and Harmata, 2001), but this charcoal has not been studied in detail. Charcoal dust coming from Meso- lithic forest clearing is present in peat bogs in the area of Polish Baltic coast (Latałowa, 1994).

Archaeologists are more interested in charcoal, though they are mostly interested in "autochthonous" charcoal - that found in excavations at ancient settlements (e.g. Madyda-Legutko, 1996; Lityńska-Zając, 1997), and not in charcoal buried in alluvium ("allochthonous"). Charcoal found during exploration of a hearth is considered as a component related in origin to the strata explored. Such charcoal is subject to taxonomical studies and radiocarbon dated in order to relate it to specific human cultures (e.g: Gluza et al., 1988; Wasylikowa et al., 1992; Lityńska-Zając, 1997; Stępnik, 2007, 2010). Local accumulations of charcoal may be of industrial origin, as is the case around the Łysogóry mountain range, where charcoal is related to ancient iron metallurgy (Bielenin and Holewiński, 1961; Orzechowski, 1991). Wood, mainly in the form of charcoal, was there the main fuel.

Alluvia in all older terraces of rivers in the mountainous part of the Carpathians are composed mainly of gravel and sand; these sediments may be weathered to a various degree. These coarse-grained sediments do not include charcoal clasts. Only the youngest terrace (floodplain) is locally built of fine-grained sediment - mud and charcoal fragments could accumulate during its accumulation. The presence of charcoal has been noted only in sediments of this youngest terrace. Local accumulations of charcoal are present in floodplain sediments of the San, Osława, Wisłok, Jasiołka, Ropa, Biała, Raba and Skawa rivers (Ślączka et al., 1991; author's personal observations), and possibly also in the rivers of the Żywiec region (Broda, 1955). This paper presents a multifaceted description of charcoal debris accumulated in alluvia of the river San and its tributaries in the Western Bieszczady range.

\section{OBJECT OF STUDY, METHODS, STUDY AREA}

The material studied in detail consisted of charcoal fragments of various size, collected from floodplain sediments. The most useful for this study were macroscopic fragments ( $>1 \mathrm{~cm}$ in diameter). These were used for taxonomic studies and absolute dating. Small charcoal fragments ( $>0.062 \mathrm{~mm}$ in diameter), and even charcoal dust obtained by sieving and washing of the samples of alluvium, were also studied. Their presence in samples of fine mineral sediment was checked under binocular microscope. Parallel with the study of charcoal fragments, granulometry of their host sediments was studied in selected vertical sections of floodplain sediments. Several samples from each section were collected in the field and grain-size distribution in each sample was then determined in laboratory. Percentage of charcoal in each grainsize class was estimated under binocular microscope.

Taxonomical analyses of most charcoal fragments were done on fragments $0.5-2 \mathrm{~cm}$ long and more than 
$0.5 \mathrm{~cm}$ in diameter. This size is sufficient to describe the anatomy of the original wood, but detailed diagnoses were done on bigger fragments $(3 \times 1 \mathrm{~cm})$. Small size of charcoal fragments in some samples prevented complete taxonomic recognition, the wood was only differentiated into that of coniferous and broadleaf trees, or the genus was recognized.

Subfossil charcoal fragments were identified in laboratory in microscope preparations oriented in three directions relative to the structure of wood: transverse, tangential and radial. Transverse sections of coarser fragments were studied using a hand lens. Identification of species was based on the key to plant classification by Schweingruber (1978). Taxonomic analyses of six charcoal samples were done at Institute of Botany, Polish Academy of Sciences in Krakow.

Selected charcoal fragments were dated using radiocarbon method. Measurements of ${ }^{14} \mathrm{C}$ concentration in charcoal samples allowed to determine their isotope age, and subsequent calibration provided calendar ages (see Pazdur and Michczyńska, 1989; Bronk Ramsey 1995, 2001; Walanus and Goslar, 2009; Bronk Ramsey et al., 2010). Fourteen charcoal samples were dated, most of them (9) in Kyiv Radiocarbon Laboratory (Ukraine), three at C-14 Laboratory of the Silesian University of Technology in Gliwice (Poland) and two at the Faculty of Physics and Nuclear Technique of AGH University of Science and Technology in Krakow (Poland). Laboratories mentioned above apply radiometric dating technique, which use decay of ${ }^{14} \mathrm{C}$ to estimate the age of samples.

The charcoal samples were collected from floodplain terraces of three rivers in the Bieszczady Mountains: the upper course of the river San, the Czarny stream (right tributary of the San debouching to the Solina dam lake) and the Jasieńka stream (right tributary of Strwiąż) (Fig. 1). The samples prove the presence of fire debris in the San valley from its headwaters near the Uzhok Pass (altitude $853 \mathrm{~m}$ ) for $75 \mathrm{~km}$ downstream to Chmiel village at the foot of the Otryt range (altitude $510 \mathrm{~m}$ ). The charcoal fragments from the Czarny and Jasieńka valleys were collected at the headwater reaches of these streams, in villages Czarna Górna and Rabe, respectively.

The presence of subfossil charcoal was proved not only in floodplain sediments of the river San but also along the tributaries of its upper course: the Niedźwiedź, Syhłowaty, Halicz, Litmirz, Muczny and Wołosaty streams. These streams drain the highest ranges of the Bieszczady Wysokie: the Pasmo Połonin range (Tarnica $1346 \mathrm{~m}$, Halicz $1333 \mathrm{~m}$ ) and the Pasmo Graniczne range (Wielka Rawka $1307 \mathrm{~m}$ ) along the border of Poland with Ukraine and Slovakia (East Carpathians). The presence of charcoal in sediments of the Czarny and Jasieńka streams proves that fire debris was produced also in the lower parts of the Bieszczady Mountains, especially in the area of the water divide between the Baltic Sea and the Black Sea.

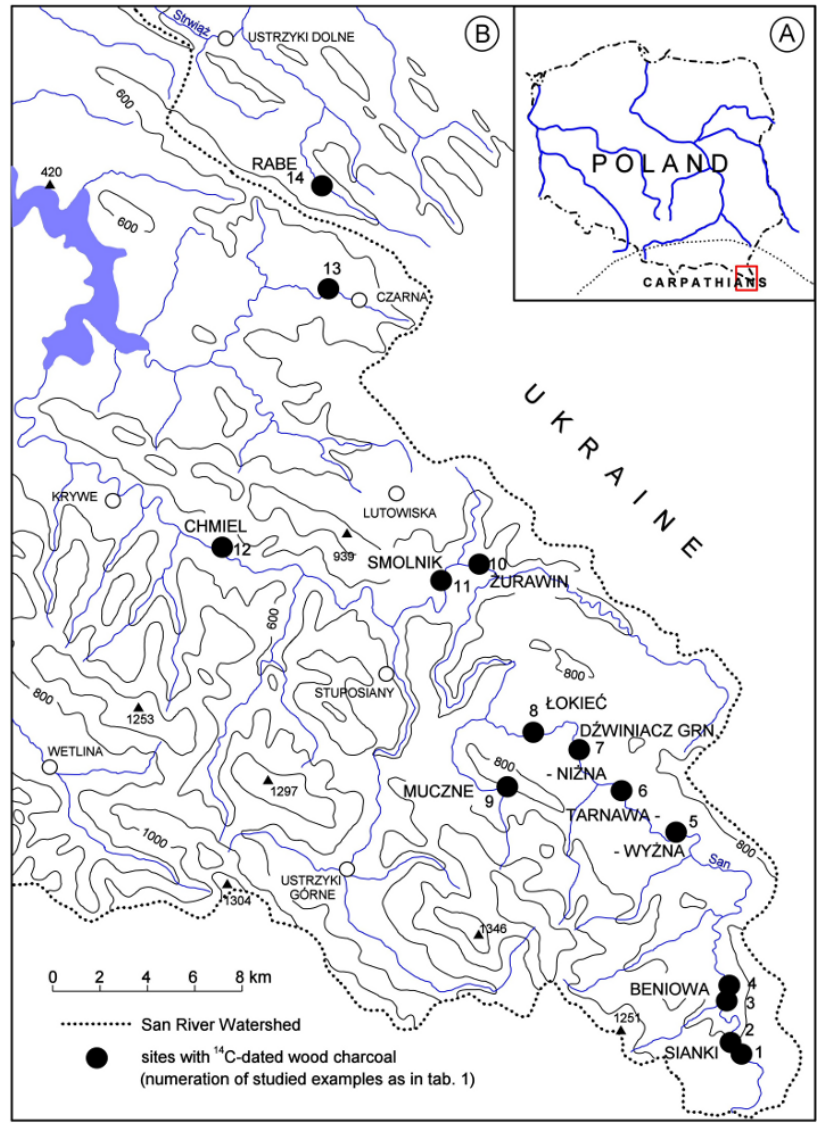

Fig. 1. Location of charcoal samples collected for absolute age determination by ${ }^{14} \mathrm{C}$ method.

The floodplain terrace of the San, in which charcoal debris is accumulated, is usually ten to twenty metres wide and only locally (Tarnawa Niżna) it broadens to $60 \mathrm{~m}$. The height of the floodplain above the stream bed rises downstream from 1 to $3 \mathrm{~m}$ and locally the terrace consists of two steps $(1.5-3 \mathrm{~m}$ and $0.5-1.5 \mathrm{~m})$. The layer of alluvium lying on the bedrock strath makes up 70 $100 \%$ of the terrace height and consists of a basal layer of gravels representing channel sediments, overlain with the layer of sandy mud representing overbank deposits. Their thickness constitutes $70-100 \%$ of the terrace height. The mud is highly enriched in charcoal near its base (Haczewski et al., 2007). The river San, though flowing through a mountain landscape, has a sinuous channel of low longitudinal gradient ( $2.6 \%$ in average).

\section{MATERIALS}

\section{Grain size and types of charcoal in alluvium}

The subfossil charcoal debris includes fragments that differ macroscopically not only in size but also in the degree of coalification and shape. Different are also parent materials that underwent coalification. 
The size of charcoal fragments in alluvium of the river San is closely related to the forms of their accumulation and to the degree of coalification. Greater accumulations usually have the form of layers or lenses $1-5 \mathrm{~cm}$ thick (areas of ancient villages Sokoliki and Łokieć), locally even $20 \mathrm{~cm}$ (Beniowa) (Fig. 2). Charcoal fragments in these greatest accumulations attain the greatest size - single clasts at Beniowa and Łokieć are up to $5 \mathrm{~cm}$ long. The charcoal clasts dispersed in mineral components of alluvial mud are not that big. Only the biggest attain $1 \mathrm{~cm}$ in length and $0.5 \mathrm{~cm}$ in diameter (area of ancient village of Tarnawa Wyżna, Chmiel), but most are much shorter and thinner $(<0.5 \mathrm{~cm})$. The macroscopic fragments are accompanied by abundant smaller particles, microscopic in size (charcoal dust). The fine particles are distinguishable only under binocular microscope, but cannot be taxonomically recognized.

The charcoal debris includes fragments that are incompletely coalified: surficially or one side only. The largest of them ( $>5 \mathrm{~cm}$ in diameter) have only the outer layers charred around unaltered cores. Other large fragments are charred at one end only, while the other is unaffected by fire (areas of ancient villages Sokoliki Górskie and Sianki). The partly coalified wood fragments are better preserved in alluvial mud. Those with thinner charred layer, or with a greater loss of this layer, have their surfaces more smoothed.

The shapes of charcoal fragments, regardless of the degree of their coalification, depend largely on the anatomy and size of original wood. Fragments of coalified thick trunks differ clearly from coalified branches. They are more wedge-like in shape and their lateral surfaces reflect the course of core radii and outlines of wide annual rings with their gentle curves. Charcoal debris from broadleaf trees, especially from their thin branches and sprouts has usually the form of straight sections, formed by transverse fracturing of wood during its burning. This

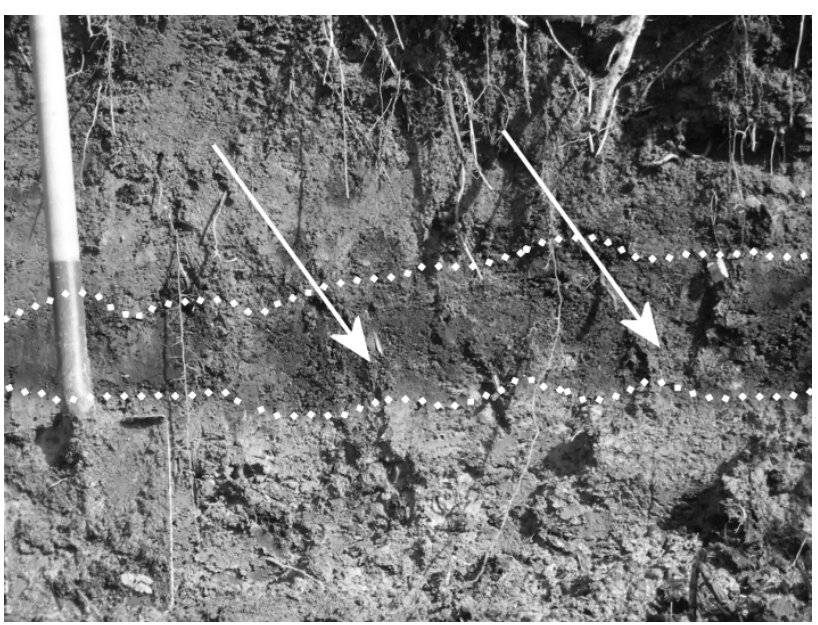

Fig. 2. Layer of charcoal debris in sediments of the river San floodplain (Beniowa). rule seems to be less strictly maintained when wet wood was burning. Also the size of charcoal fragments seems to be proportional to the thickness of branches and their wetness during burning. The wetter the wood was, the more diversified in shape are the charcoal fragments left from it.

The irregularly shaped charcoal fragments include also remnants of bark. Their coalification is often incomplete in consequence of the high density and hardness of bark. Similar are properties of coalified debris of bracket fungi. Charred bracket fungus is harder than charred wood and its surface is not readily smoothed by abrasion, even during fluvial transport. Also incompletely burnt resin retains hardness and glossy fracture.

\section{Position of charcoal debris in alluvium}

Charcoal is concentrated at two positions in vertical sections of the river San alluvium: near the base (accompanied by wood debris) and in the middle part. The basal part of the section is enriched in charcoal, especially coarse charcoal fragments, incompletely burnt wood fragments and coarse fragments of wood charred only superficially. Charcoal debris in the middle part of the section is finer and dispersed in mineral sediment. It forms, however, a clearly discernible horizon (Tarnawa Niżna, Dźwiniacz Górny, Sianki). At both positions in the section, greater concentrations of charcoal are locally present in the form of thin layers or lenses (Fig. 3) composed of charcoal only or of charcoal mixed with noncharred wood and mineral components (Łokieć, Beniowa, Sianki, Wołosate). Along the river San two levels with charcoal occur in the same section of the floodplain sediments only sporadically (Beniowa, Tarnawa Wyżna, Chmiel; Fig. 3), usually only one of the levels is present. In alluvial muds of the San tributaries (the Niedźwiedź, Halicz, Litmirz, Muczny streams) and along the Jasieńka stream, the presence of the two horizons with charcoal debris is less distinct; charcoal is dispersed in the whole vertical section of the floodplain alluvium. Along the

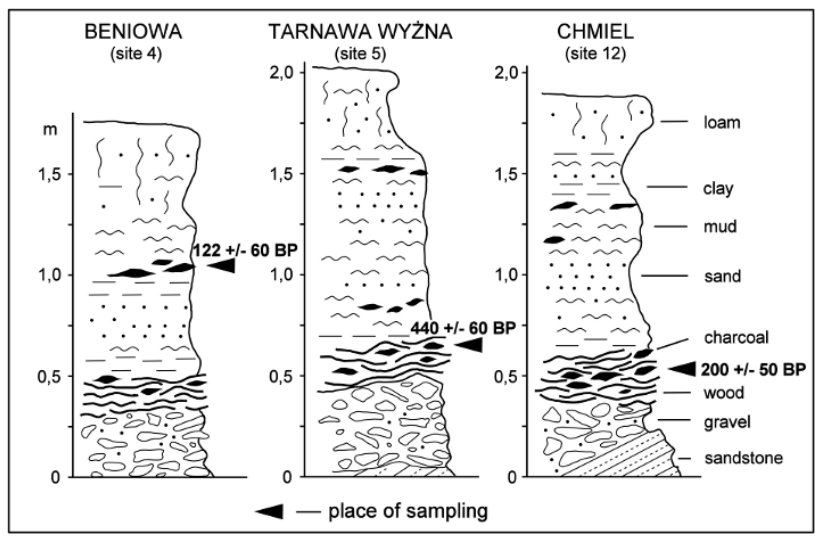

Fig. 3. Horizons of charcoal debris in floodplain alluvium of the river San. Lithological symbols explained on the right site. 
Wołosatka and Wołosaty streams, from the vicinity of the Beskid Pass in Wołosate downstream to Ustrzyki Górne, charcoal debris is present mostly at the base of alluvial mud. The upper part of the mud consists of coarser mineral sediments.

Analyses of grain-size and composition of the samples of alluvial mud collected along the river San have shown that charcoal debris is present in all the studied vertical sections of the terrace alluvium but in various amounts. The charcoal debris is present along the whole sections and in almost all size classes (Kukulak, 2005). The finer a mineral sediment is, the finer charcoal debris it contains. Concentration of charcoal fragments and charcoal dust increases with fining of the grain-size of the host mineral sediment. The greatest concentrations (even up to $3 \%$ ) occur in fine mud. They come probably from direct disintegration of burning wood or from later fragmentation of charcoal clasts during fluvial transport. Accumulations of charcoal debris, similarly as accumulations of unburnt wood debris, are characteristically coarser grained than their host sediment; for instance mediumgrained sand $(<0.5 \mathrm{~mm})$ contains charcoal fragments several times coarser (up to several millimetres). Grainsize distribution in vertical sections of alluvial mud seems to be the factor controlling the uneven concentration of charcoal debris.

\section{RESULTS}

\section{Dating of charcoal}

Radiocarbon dating was done for charcoal fragments collected from the two levels in the alluvial mud sections: from the basal part (9 samples) and from the middle part (5 samples). Coal fragments in each sample came from a single accumulation but from various size classes (0.3$1.0 \mathrm{~cm}$ in length). Taxonomical identification of the charred samples was not possible macroscopically. Dated wood fragments were charred to a different degree (charcoal, unburnt remnants), but their small size prevented determination from which part of tree they came from. Charcoal fragments left after washing out of mineral sediment were not used for dating. Spatial distribution of the dated charcoal fragments (Fig. 1) shows the degree of spatial synchronicity of charcoal deposition in alluvial sediments of the rivers San and Strwiąż.

The age of subfossil charcoal (determined using ${ }^{14} \mathrm{C}$ ) is generally young and constrained within a narrow time interval (Table 1). The older dates correspond to charcoal debris from the basal part of the alluvial mud section, the younger ones - to those in the stratigraphically higher level. The oldest dates obtained correspond to the beginnings of the $15^{\text {th }}$ century, in sample 8 (Łokieć) even 9$12^{\text {th }}$ century, and do not necessarily reflect the time of their deposition in alluvium. Moreover, the upper age limit of this charcoal debris is 1-2 centuries younger. The presence of charcoal debris yielding the oldest dates indicates the maximum age of the charcoal-bearing alluvium on the floodplain of the river San. The age of this charcoal debris is partly corroborated by similar age of the accompanying debris of uncharred wood buried in the basal part of the alluvial mud (Kukulak et al., 2002; Kukulak, 2004). It may be thus accepted that accumulation of the fine-grained alluvium in the valleys of the San and Strwiąż began in late Medieval time. Only the age of charcoal in sample 8 (Łokieć) departs from this scheme. Charred wood fragments in this sample are older by a few hundred years and we have no data to prefer any of possible explanations.

Charcoal debris in the higher parts of the alluvial mud section is younger by a few centuries (150-400 years). The upper limit of its age reaches the second half of the $18^{\text {th }}$ century, and in some cases even to the $20^{\text {th }}$ century (Tarnawa Niżna). This indicates that accumulation of charcoal debris in alluvium of the floodplain continued over centuries with deposition of alluvium.

\section{Taxonomic analysis of charcoal}

Taxonomy of source wood of the charcoal debris fragments was determined on samples from six sites and the two horizons rich in charcoal debris in floodplain alluvium of the San and Strwiąż river basins. The number of examined fragments at individual sites varied from 13 to 81. Other charcoal fragments collected at these sites were too small for reliable taxonomic analysis.

Taxonomic composition of charcoal source wood is rather uniform at all studied sites (Table 2). Predominant are coniferous trees: fir and spruce; much lower is participation of beech and alder. Charcoal fragments from alder and maple occur subordinately. The charcoal fragments determined as Picea/Larix most likely represent spruce, as larch was and still is a rare species in the upper San drainage basin (Zarzycki, 1963; Rygiel, 1987). Samples from the basal part of alluvial mud ( 5 sites) are dominated by charcoal from fir and spruce, with a smaller amount of beech and alder. Charcoal fragments from alder and maple are subordinate. In the higher part of alluvial mud (Tarnawa Niżna) predominates charcoal from broadleaf trees, mainly alder.

The composition of charcoal debris remains similar over the whole studied length of the river San. The data in Table 2 show that charcoal fragments derived from fir are three times as numerous as those from spruce, and among the broadleaf trees charcoal fragments from beech are twice as numerous as those from alder, while maple and birch are represented by single fragments only. The proportions between the species in charcoal fragments are similar to those in uncharred wood debris. Predominance of fir in the studied samples may be the result of preferential selection of this species for practical needs. Charcoal debris from Sianki included artificially cut fragments of fir wood.

Taxonomic composition of the studied charcoal debris does not necessarily reflect the species composition of forests in the upper drainage basin of the river San, 
Table 1. Results of dating of studied charcoal debris from the upper reaches of the river San (I-XIII) and the Strwiąż river (XIV). Calibration of the radiocarbon dates (expressed as cal years AD time intervals with probability 95.4\%) was done using the calibration data set IntCal13 (Reimer et al., 2013) and OxCal (version 4.2) calibration program (Bronk-Ramsey et al., 2010). Source: Kukulak, 2005 (* — supplemented).

\begin{tabular}{|c|c|c|c|c|}
\hline $\begin{array}{l}\text { Sample } \\
\text { number }\end{array}$ & $\begin{array}{c}\text { Sample name I } \\
\text { Laboratory Code }\end{array}$ & ${ }^{14} \mathrm{C}$ age (BP) & $\begin{array}{c}\text { Calibrated age } \\
\text { (range } 95.4 \% \text { ) cal AD }\end{array}$ & $\begin{array}{c}\text { Position } \\
\text { (depht of sample in section) }\end{array}$ \\
\hline 1 & $\begin{array}{c}\text { Sianki I } \\
\text { Gd-12619 }\end{array}$ & $245 \pm 50$ & $\begin{array}{c}1480-1700(60.0 \%) \\
1720-1820(26.7 \%) \\
1920-\ldots(8.8 \%)\end{array}$ & $\begin{array}{c}\text { basal part } \\
(0.9-1.0 \mathrm{~m})\end{array}$ \\
\hline 2 & $\begin{array}{l}\text { Sianki III } \\
\text { Ki-10065 }\end{array}$ & $345 \pm 60$ & $1440-1650(95.4 \%)$ & $\begin{array}{l}\text { basal part } \\
(1.1-1.3 \mathrm{~m})\end{array}$ \\
\hline 3 & $\begin{array}{l}\text { Beniowa I } \\
\text { Ki-10067 }\end{array}$ & $410 \pm 70$ & $1410-1650(95.4 \%)$ & $\begin{array}{l}\text { basal part } \\
(0.7 \mathrm{~m})\end{array}$ \\
\hline 4 & $\begin{array}{l}\text { Beniowa II } \\
\text { KR-168 }\end{array}$ & $122 \pm 60$ & $1660-1950(95.4 \%)$ & $\begin{array}{c}\text { middle part } \\
(0.65-0.75 \mathrm{~m})\end{array}$ \\
\hline 5 & $\begin{array}{l}\text { Tarnawa Wyżna } \\
\text { Ki-10073 }\end{array}$ & $440 \pm 60$ & $\begin{array}{c}1330-1340(0.4 \%) \\
1390-1640(95.0 \%)\end{array}$ & $\begin{array}{c}\text { basal part } \\
(1.8 \mathrm{~m})\end{array}$ \\
\hline 6 & $\begin{array}{c}\text { Tarnawa Niżna } \\
\text { Ki-10078 }\end{array}$ & $180 \pm 60$ & $1640-\ldots(95.4 \%)$ & $\begin{array}{l}\text { middle part } \\
(2.2 \mathrm{~m})\end{array}$ \\
\hline 7 & $\begin{array}{l}\text { Dźwiniacz Grn. } \\
\text { Gd-15647 }\end{array}$ & $270 \pm 100$ & $\begin{array}{c}1440-1890(88.2 \%) \\
1910-\ldots(7.2 \%)\end{array}$ & $\begin{array}{c}\text { basal part } \\
(2.0 \mathrm{~m})\end{array}$ \\
\hline 8 & $\begin{array}{c}\text { Łokieć } \\
\text { Ki-10085 }\end{array}$ & $1030 \pm 70$ & $\begin{array}{c}770-790(0.8 \%) \\
820-850(0.7 \%) \\
860-1170(93.9 \%)\end{array}$ & $\begin{array}{l}\text { basal part } \\
(1.7 \mathrm{~m})\end{array}$ \\
\hline 9 & $\begin{array}{l}\text { Muczne } \\
\text { Ki-10086 }\end{array}$ & $380 \pm 80$ & $1400-1670(95.4 \%)$ & $\begin{array}{c}\text { basal part } \\
(1.5 \mathrm{~m})\end{array}$ \\
\hline 10 & $\begin{array}{l}\text { Żurawin* }^{*} \\
\text { Gd-12634 }\end{array}$ & $200 \pm 60$ & $\begin{array}{l}1520-1560(3.4 \%) \\
1630-\ldots(92.0 \%)\end{array}$ & $\begin{array}{l}\text { middle part } \\
(2.7 \mathrm{~m})\end{array}$ \\
\hline 11 & $\begin{array}{l}\text { Smolnik* }^{*} \\
\text { KR-195 }\end{array}$ & $300 \pm 70$ & $\begin{array}{c}1440-1690(86.2 \%) \\
1730-1810(7.1 \%) \\
1930-\ldots(2.1 \%)\end{array}$ & $\begin{array}{l}\text { middle part } \\
(1.5 \mathrm{~m})\end{array}$ \\
\hline 12 & $\begin{array}{l}\text { Chmiel }^{*} \\
\text { Ki-10091 }^{2}\end{array}$ & $200 \pm 50$ & $\begin{array}{l}1530-1540(0.6 \%) \\
1630-\ldots(94.7 \%)\end{array}$ & $\begin{array}{c}\text { middle part } \\
(1.25-1.35 \mathrm{~m})\end{array}$ \\
\hline 13 & $\begin{array}{l}\text { Czarna Górna* } \\
\text { Ki-10092 }\end{array}$ & $180 \pm 40$ & $\begin{array}{c}1640-1820(67.2 \%) \\
1830-1890(9.4 \%) \\
1910-\ldots(18.7 \%)\end{array}$ & $\begin{array}{c}\text { basal part } \\
(0.65-0.75 \mathrm{~m})\end{array}$ \\
\hline 14 & $\begin{array}{l}\text { Rabe } I^{*} \\
\text { Ki-10093 }\end{array}$ & $220 \pm 60$ & $\begin{array}{l}1510-1600(11.6 \%) \\
1610-\ldots(83.8 \%)\end{array}$ & $\begin{array}{l}\text { basal part } \\
(0.7-0.8 \mathrm{~m})\end{array}$ \\
\hline
\end{tabular}

Ki - Kiev Radiocarbon Laboratory, Ukraine; Gd - Gliwice Radiocarbon Laboratory, Poland; KR - AGH - University of Science and Technology, Faculty of Physics and Nuclear Techniques in Krakow, Poland

Table 2. Taxonomy of charcoal source wood from floodplain alluvium of the upper river San valley. Source: Kukulak, 2004.

\begin{tabular}{|c|c|c|c|c|c|c|c|c|c|}
\hline \multirow[b]{3}{*}{$\begin{array}{l}\text { Latin } \\
\text { name }\end{array}$} & \multirow[b]{3}{*}{$\begin{array}{c}\text { English } \\
\text { name }\end{array}$} & \multicolumn{6}{|c|}{ Site name (see Fig. 1) } & \multirow{3}{*}{\multicolumn{2}{|c|}{$\frac{\widehat{a}}{\bar{a}}$}} \\
\hline & & $\mathrm{I}$ & II & III & IV & V & $\mathrm{VI}$ & & \\
\hline & & $\begin{array}{l}\equiv \\
\text { 三 } \\
\text { 竞 } \\
\text { क }\end{array}$ & 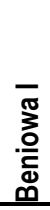 & 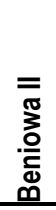 & 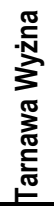 & 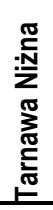 & بَّ & & \\
\hline \multicolumn{10}{|l|}{ Hardwood: } \\
\hline Acer sp. & Maple & 1 & - & - & - & - & - & 1 & 0.4 \\
\hline Alnus sp & Alder & 4 & - & - & 1 & 8 & 1 & 14 & 5.5 \\
\hline Betula sp. & Birch & - & - & - & - & 1 & - & 1 & 0.4 \\
\hline Fagus silvatica & Europeanbeech & - & - & - & 6 & 13 & 8 & 27 & 10.5 \\
\hline \multicolumn{10}{|l|}{ Coniferous: } \\
\hline Abies alba & European silver fir & 6 & 86 & 23 & 15 & 13 & 5 & 148 & 59.0 \\
\hline Picea abies & Norway spruce & - & - & - & - & 1 & - & 1 & 0.4 \\
\hline Picea/Larix & Spruce/Larch & 2 & 1 & 18 & 10 & 1 & 27 & 59 & 23.8 \\
\hline
\end{tabular}


especially proportions between individual species. Local modifications of this composition could be caused by natural (e.g. riparian nature of trees) and artificial causes (selective burning of some tree species). This seems to be the case with the studied charcoal debris, where proportions between seem to be different from those in actual forest. Proportions between tree groups in the $16^{\text {th }}-17^{\text {th }}$ century were different; conifers were in minority (Schramm, 1958; Fastnacht, 1962; Rygiel, 1998). Palaeobotanical data also confirm that broadleaf forest predominated in the Bieszczady Mountains at the transition from Mediaeval to modern times (Ralska-Jasiewiczowa, 1980).

\section{ORIGIN OF CHARCOAL IN ALLUVIUM - SLASH BURNING}

Comparison of the age distribution of the dated charcoal fragments with historical data on settlement in the Bieszczady Mountains reveals distinct temporal correlations. Charcoal in the alluvial mud of the river San is clearly related to human presence and seems to be a result of intentional human activity in this part of the Bieszczady Mountains. The charcoal is of local provenance as it occurs in alluvium of the upper parts of the San and Strwiąż drainage basins.

The use of fire in land management is associated with early stages of human activity registered, for instance, as local changes in forest plant communities discerned in peat bog sections. Dimbleby (1961) and Mason (2000), among others, report such changes in the British Isles and in Scandinavia to the Mesolithic Period (8300-6000 years BP). The works by Machnik (1993) and Latałowa (1994) indicate that slash burning economy became widespread in Central and Western Europe already in the $4^{\text {th }}$ $3^{\text {rd }}$ millennia BP. In Poland this method was then used mainly in the upland areas of Małopolska (e.g. Kruk, 1973, 1983; Wiślański, 1979; Wasylikowa, 1983; Godłowski, 1983). In early Mediaeval time this method was extensively used in the areas of Germany (InamaSternegg, 1879), France (Lamprecht, 1978; Vanniere et al., 2000), Moravia and Scandinavia (Pitkanen and Hettunen, 1999). In Poland this system of land use became predominant in late Mediaeval times (Broda, 1952, $1955)$, and in Russia it was still common during the $17^{\text {th }}$ $19^{\text {th }}$ centuries (Trietiakow, 1948).

Charcoal and ash to alluvia of mountain streams in the Carpathians were most likely supplied from the areas of slash-and-burn economy on valley slopes. Slash-and-burn economy, widely used at that time, was the main source of charcoal. This method of land use was common in Medieval time (Żaki, 1955; Hejnosz, 1960; KowalskaLewicka, 1961; Starkel, 1987). Slash-and-burn economy was the basic way of land management when colonization of the Beskidy Mountains began (Kubijowicz, 1926; Moszyński, 1929; Broda, 1952) and it persisted to modern times on the grounds that were developed last (Żaki, 1955; Broda, 1955). It used to be a usual way of rural agriculture till the middle of the $19^{\text {th }}$ century (KowalskaLewicka, 1961).

The age of subfossil charcoal in the Bieszczady Mountains corresponds to two periods of intense forest clearance and use of fire in this area. The first is related to the beginning of agricultural settlement in the San valley $\left(15-16^{\text {th }}\right.$ century). Slash-and-burn was then commonly used to expand farming grounds and fertilize them (Kubijowicz, 1926; Tokarz, 1909; Reinfuss, 1939). Burning of wood intensified again in the $18^{\text {th }}-19^{\text {th }}$ century, when numerous asheries worked in the Bieszczady Mountains (Sianki, Beniowa, Bukowiec, Tarnawa Wyżna, Dźwiniacz Górny, Smolnik), producing potash from wood ash in locations near stream channels (Augustyn, 1999). Charcoal was also produced for blacksmithery. These two periods of intense wood burning could have left their record as debris of charred wood, charcoal fragments and charcoal dust in alluvia of the San and its tributaries. Some fraction of charcoal debris and coarse fragments of partly burnt wood may represent incompletely burnt remnants not only from fire sites but also from household ovens (Kadrow and Lityńska-Zając, 1994). Houses in the villages in the Bieszczady Mountains were concentrated along the channel of the San and its tributaries.

Anthropogenic origin of charcoal is also indicated by traces left by tools on wood before burning; charcoal debris from Sianki and Łokieć includes partly burnt fragments of household utensils. It is not certain when the slash-and-burn economy ceased to be used in the Bieszczady Mountains. It is likely that locally burning out of bush and sprouts lasted till the end of the agricultural stage in the history of the Boiko people, not only at valley bottoms but also near the treeline, just below the mountain pastures.

The upper part of the San valley was colonized by farmers in 15-16 ${ }^{\text {th }}$ centuries (Fastnacht, 1962). The needs of herding and cultivation called for clearing of forests, as the valley was earlier occupied mostly by woods. Slashand-burn economy was used not only by the first generations of settlers but also by Valachian migratory herders. Clearing of forests in river valleys had the goal of gaining ground for settlement and agriculture (Tokarz, 1909; Fastnacht, 1962; Reinfuss, 1939; Augustyn,1999), and on alpine meadows - for herding cattle and sheep (Rehman, 1895; Kubijowicz, 1926; Schramm, 1956; Zarzycki, 1963). Localized burning of easily accessible plots within forest resulted in isolated pastures or arable plots (Rehman, 1895; Broda, 1952). Considering labourintensive character of transforming clearcuts or fireplaces into pastures or arable fields, transformation of land by slash-and-burn had to be less common at alpine meadows than in valley bottoms (Broda, 1952; Tunia, 1986).

Forest clearance by slash-and-burn was realized in the Bieszczady, similarly as in other parts of the Carpathians, in various ways (e.g. Kubijowicz, 1926; Broda, 1952; Kowalska-Lewicka, 1961; Tunia, 1986). Wood was usually burned at sites of clearance and the resulting ash was 
dispersed over the burnt plots to fertilize soil for grain cultivation. At that time this was the only way to improve soil productivity. Ash from wood is a potassiumphosphorus fertilizer with subordinate content of calcium, which contributes to the loosening of soil structure. Burning of forest and brush was only an introductory stage in the clearance of the terrain for later permanent cultivation (Śląski, 1965). Piles of wood covered with sod were burnt until the sod was completely charred. Grain was sown directly into ash and the charred upper layer of soil without ploughing. Soil remained fertile enough for several years, until it became barren and slash burning moved to a new plot of forest. The abandoned fields became fallow and then were invaded by woods. After some $20-30$ years the new growth was burnt again. Rapid rotation of slash burning sites resulted in covering extensive area of forested lands with slash-and-burn economy.

Deforestation by slash-and-burn management diminished in the Bieszczady Mountains only in the $17-19^{\text {th }}$ century. It was replaced by industrial production of potash from ash. This was especially intensive in forests less suitable for conversion into farming grounds, it also helped to get rid of surplus amounts of wood, mostly hardwood, less suitable for practical use (Śląski, 1965). Potash was mainly produced from beech wood, hence asheries were usually placed inside or at margins of beech forests. Wood was burnt in specially constructed kilns. In sites removed from the kilns, trunks and branches were burnt directly on ground. Potash making required large amounts of water and wood fuel, hence the kilns were located near streams or reservoirs built specially for this purpose (Fig. 4). Some amounts of ash and charcoal got to streams during the process of potash production and could be transported until their deposition with mineral material. According to Broda (1955), Śląski (1965) and Augustyn (1999), some potash kilns operated for short periods or changed their locations (usually each 5 years) because of rapid using up of nearby fuel. Loss of forest for potash production in one ashery could amount to more than 100 ha of forest, as was the case at Bukowiec on the Halicz stream in the $19^{\text {th }}$ century. The demise of the asheries near the end of the $19^{\text {th }}$ century was accompanied by the appearance of charcoal burning industries, which became another source of fire debris to stream channels.

This course of development of wood burning in the Bieszczady Mountains over the last five centuries is reflected not only in synchroneity of subfossil charcoal debris in alluvium of the river San, but also in the results of taxonomic analysis of the charcoal source wood. The large concentration of charcoal debris near the base of alluvial mud may be explained by the greatest extent of slash-and-burn economy in the initial phase of agricultural colonization $\left(15^{\text {th }}-17^{\text {th }}\right.$ century). The layers of charcoal in the middle part of the alluvial mud section reflect burning of wood for industrial purposes in the $18^{\text {th }}-19^{\text {th }}$ century. The increase in concentration of charcoal dust in the higher parts of the alluvial mud section was related to the appearance and activity of asheries in the $18^{\text {th }}-19^{\text {th }}$ centuries (Strzelecki, 1900; Broda, 1965; Kryciński, 1995; Augustyn, 1999). The predominance of charcoal from coniferous trees in the basal part of the alluvial mud may be the result of selective felling and burning of spruce and fir at the early stage of the San valley colonization $\left(15^{\text {th }}-17^{\text {th }}\right.$ centuries $)$. Taxonomic composition of the studied charcoal source wood may be dominated by the tree species that were less numerous but were useless as wood and easier accessible (Fastnacht, 1962). This could have been also the result of selecting those tree species that were more useful (Smart and Hoffman, 1988). The forests burnt in valleys, in sites best fitted for agriculture, represented the tree assemblage characteristic of the lowest forest storey, that of lower mountain forest, rather than the tree composition in the Bieszczady Mountains as a whole. The predominance of charcoal from broadleaf trees in the higher part of the alluvial mud section may be due to preferential burning of alder and beech in asheries in the $18^{\text {th }}-19^{\text {th }}$ century (Augustyn, 1999), as more effective in providing ash.

\section{FLUVIAL PALAEOENVIRONMENT - CHAR- COAL RESISTIVITY, MODE OF SEDIMENTA- TION}

Charred wood was washed to streams from the sites of burning and buried in alluvium together with mineral sediment. The process of downslope washing is recorded by layers of charcoal debris in slope deluvium (e.g. at Tarnawa Wyżna, Łokieć, Wołosate, Ustrzyki Górne, Brzegi Górne, Wetlina). Charcoal dust and ash are readily washed out from soil because they form weakly consolidated agglomerates with mineral particles.

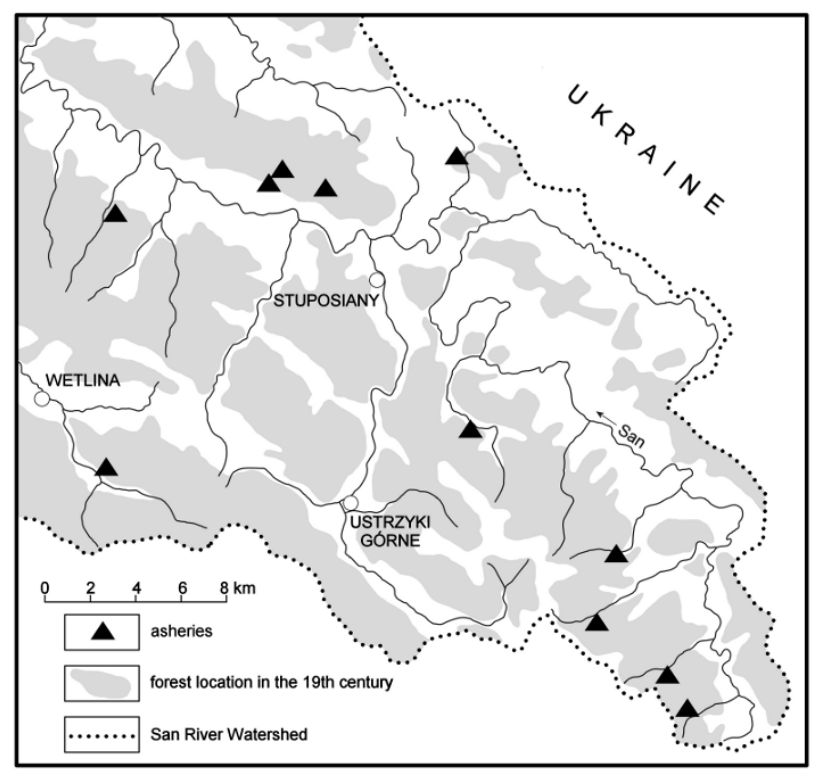

Fig. 4. Distribution of asheries relative to forest areas in $2^{\text {nd }}$ half of $19^{\text {th }}$ century. 
Charcoal is easily transported by water because it has lower density than wood. Structure of wood cell walls is damaged, to the greater degree with higher temperature or deeper its penetration (Fig. 5). Fine charcoal fragments are frequently carried in suspension, less commonly in traction. Only large water soaked charcoal fragments are transported by saltation and these often break down. They usually disintegrate along growth rings (Lityńska-Zając 1997); the broadleaf species usually fall into longitudinal sections (alder) or into irregular fragments. Individual species differ in their susceptibility to mechanical breakdown. Charcoal from the hardest wood breaks down into less numerous, but greater fragments, as is the case with ash or oak. The abundance of coalified bark and roots in alluvium results also from their greater hardness and resistance to erosion, especially if they come from old beech, pine and larch (Mowszowicz, 1956; Nichols et al., 2000). Wood from spruce and pine burns easily and usually completely because of its thin bark and shallow root systems. Charcoal fragments from these species are usually finer, e.g. pine wood usually has a tendency to disintegrate into fine fragments along the annual growth rings (Gluza et al., 1988).

Charcoal dust and coarser charcoal fragments are deposited mainly on floodplain, together with slightly finer fragments of wood and with mineral sediment finer than charcoal or wood by 2-3 divisions on the granulometric phi scale. Coarser fragments of charcoal are deposited also on natural levees (e.g. at the site of the ancient village Beniowa). Dispersion of charcoal debris in the whole layer of the river San alluvial mud may be the result of various modes of fluvial transport or of local erosion and redeposition of alluvium during the period of alluvial mud accumulation. Grain-size characteristics of alluvial mud in its longitudinal and transverse sections seem to be the factor controlling concentration of charcoal debris. Charcoal seems to be the most abundant in overbank sediments, where mineral fraction is finest.

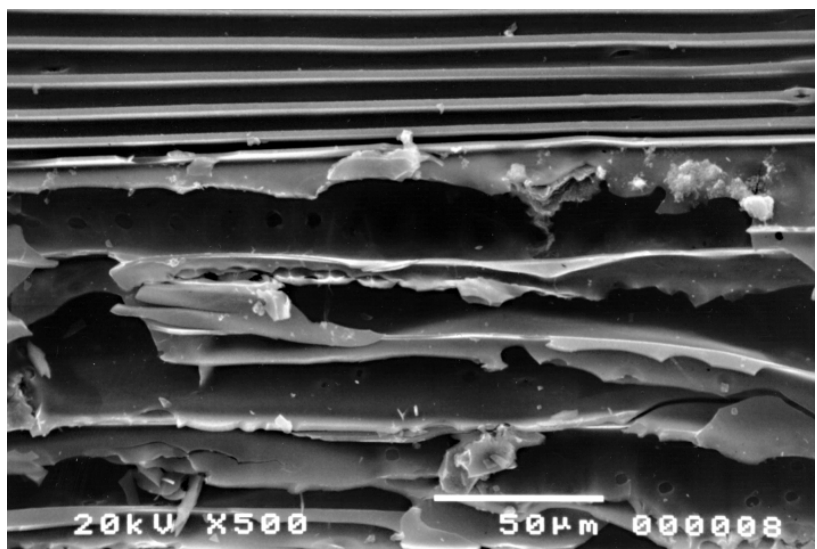

Fig. 5. Fire damage in anatomy of conifer wood (Beniowa II) in scannig microscope.
Subfossil charcoal is more durable than uncharred wood (Tinner et al., 1998; Ohlson and Tryterud, 2000; Schmidt and Noack, 2000). It does not weather because of its burial in mud. Quality of charcoal preservation depends also strongly on the degree of wood coalification and on the species of the source wood. By taking into account unequal natural resistivity of buried charcoal from various tree species we may infer that the predominance of conifer species among the trees burnt during the first centuries of colonization in the Bieszczady Mountains $\left(15^{\text {th }}-16^{\text {th }}\right.$ centuries $)$ was not as large as the proportions in preserved charcoal suggest. After five hundred years uncharred remnants of fir wood buried in mud are preserved better than those of alder wood (Kukulak, 2004); it is possible that this also holds true for charcoal. Some part of older charcoal from alder trees could thus be eliminated during fluvial transport and become disintegrated into small fragments and charcoal dust, not recognizable in taxonomic analysis.

The wide extent of fire material in alluvium is partly the result of wide dispersal of fire sources over the large part of the river San drainage basin; the extent was additionally enlarged by fluvial transport. Unlike the pointlike accumulations of charcoal at archaeological sites, the appearance of charcoal in alluvium delineates the extent of the area where slash-and-burn economy was used.

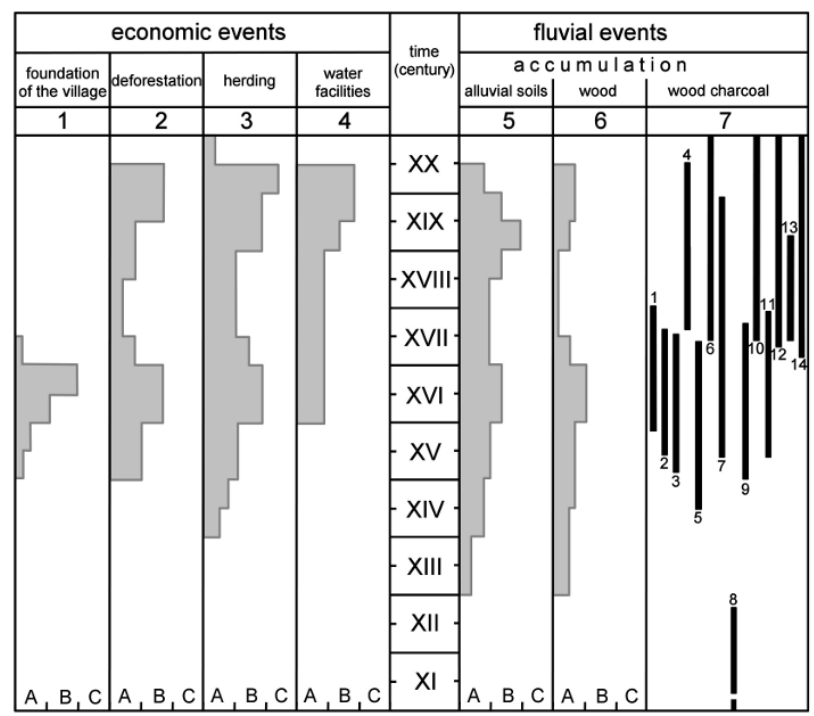

Fig. 6. Correlation of charcoal age with the course of human activity in headwaters of the river San.

Intensity of processes: $A$ - negligible; $B$ - medium; $C$ - intense.

The intensity of processes in columns 1-4 was established basing on: Schramm, 1958; Augustyn, 1999; Fastnacht, 1962; Kryciński, 1995; Rygiel, 1998; in columns 5-7 was estimated on the author's data.

Column 7 shows position of the studied charcoal samples (1-14) on time axis of anthropogenic and fluvial processes in the upper courses of the rivers San and Strwiąż. Age of charcoal in individual samples is shown in the maximum confidence interval (as in Table 1). 


\section{CONCLUSIONS}

Multifaceted analysis of subfossil charcoal provides data on origin, conditions of transport and deposition of the charcoal and its durability in alluvial sediments. It is a carrier of the following information on palaeogeography of the source area:

1) Origin of charcoal in alluvium of the rivers San and Strwiąż is related to human activity (Fig. 6) which included fire clearance of forests (the older stage of charcoal accumulation in alluvium) and industrial production of charcoal from wood (the younger stage).

2) The absolute ages suggests that this activity took place mostly from $15^{\text {th }}$ to $19^{\text {th }}$ century, locally even to the middle of the $20^{\text {th }}$ century.

3) The taxonomic analysis of charcoal indicates that all species of trees were burnt then, though conifer wood prevails in older charcoal, and deciduous trees in the younger. The taxonomic composition of the studied charcoal and the amounts of macroscopic debris may be related to various resistance to transport and various degree of coalification.

4) The wide areal extent of the fire debris in alluvium demonstrates that the sites of fire were dispersed over a large area of the drainage basin. Accumulation of charcoal in alluvium was enhanced by contemporaneous change in type of alluvium from gravel to sandy muds.

\section{ACKNOWLEDGEMENTS}

The results presented above were obtained mainly within the scope of research project 3 P04E02524 funded by Committee of Scientific Research, and supplemented during later studies. I thank Ing. Zofia Tomczyńska (Institute of Botany, Polish Academy of Sciences, Kraków) for taxonomic analysis of charcoal fragments, M.Sc. Jadwiga Faber (Zoological Institute, Jagiellonian University, Kraków) for photographic documentation of the fire material in sediment samples and Dr Grzegorz Haczewski for valuable discussion and translation of the text to English. I thank the anonymous authors of two detailed and helpful reviews for their contribution to the improvement of the manuscript.

\section{REFERENCES}

Augustyn M, 1999. Wpływ produkcji potażu na stan lasów nad górnym Sanem i Solinką w XIX wieku (Effect of potash production in the state forests on the upper San and Solinka in the nineteenth century). Roczniki Bieszczadzkie 8. Ustrzyki Dolne: 299-324 (in Polish).

Bieroński J, Chmal H, Czerwiński J, Klementowski J and Traczyk A, 1992. Współczesna denudacja w zlewniach górskich Karkonoszy (Contemporary denudation in mountain Karkonosze catchments). In: Kotarba A, ed., System denudacyjny Polski (Polish denudation system). Prace Geograficzne IGiPZ PAN 155: 151-169 (in Polish).
Broda J, 1952. Gospodarka zrębowo-wypaleniskowa w Beskidzie Żywieckim (Slush burning economy in the Beskid Żywiecki). Slavia Antiqua, III: 209-288 (in Polish).

Broda J, 1955. Chłopskie karczunki wypaleniskowe na Żywiecczyźnie w okresie gospodarki folwarcznej (Fire clearance of forests by peasants in the Żywiec region in the period of manorial economy). Wierchy 24, Kraków: 19-42 (in Polish).

Broda J, 1965. Eksploatacja lasu przez chłopów i mieszczan. Eksploatacja lasu przez dwór (Operation of the forest by the peasants and townspeople. Operation of the forest by the court). In: Dzieje lasów, leśnictwa i drzewnictwa w Polsce. Warszawa: 80-100 (in Polish).

Bielenin K and Holewiński S, 1961. Rudki - starożytny ośrodek górniczy w Górach Świętokrzyskich (Rudki - ancient mining center in the Świętokrzyskie Mountains). Przegląd Geologiczny 3: 134-138 (in Polish).

Bronk Ramsey C, 1995. Radiocarbon calibration and analysis of stratigraphy: The OxCal Program. In: Cook GT, Harkness DD, Miller BF and Scott EM, eds., Proceedings of the $15^{\text {th }}$ International Radiocarbon Conference, June 15-19 August, 1994, Glasgow, Scotland. Radiocarbon 37(2): 425-430.

Bronk Ramsey C, 2001. Development of the radiocarbon calibration program. Radiocarbon 43(2A): 355-363.

Bronk Ramsey C, Dee M, Lee S, Nakagawa T and Staff R, 2010. Developments in the calibration and modeling of radiocarbon dates. Radiocarbon 52(3): 953-651.

Chandler CP, Cheney R, Thomas P, Trabaud L and Willams D, 1983. Fire in forestry. Part I. John Wiley \& Sons, New York: 450pp.

Dimbleby GW, 1961. The ancient forest of Blackamore. Antiquity 35: $123-128$.

Dumanowski B, Jahn A and Szczepankiewicz S, 1962. The Holocene of Lower Silesia in the light of results of the radiocarbon dating. Bulletin de l'Académie Polonaise des Sciences, Série des sciences Chimiques, Géologiques et Géographiques 10(1): 47-52.

Fastnacht A, 1962. Osadnictwo ziemi sanockiej w latach 1340-1650 (The Sanok region settlement between 1340-1650). Prace Wroctawskiego Towarzystwa Naukowego, ser. A(84): 291pp (in Polish).

Gębica P and Krąpiec M, 2009. Young Holocene alluvia and dendrochronology of subfossil trunks in the river San valley. Studia Geomorphologica Carpatho-Balcanica 43. PAN Kraków: 63-75.

Gluza I, Tomczyńska Z and Wasylikowa K, 1988. Uwagi o użytkowaniu drewna w neolicie na podstawie węgli drzewnych ze stanowisk archeologicznych w Krakowie - Nowej Hucie (Notes on the use of wood in the Neolithic based on charcoal from archaeological sites in Krakow - New Huta). Materiaty Archeologiczne Nowej Huty 12: 7-25 (in Polish).

Godłowski K, 1983. Człowiek a środowisko w okresie lateńskim, rzymskim i wędrówek ludów (Man and environment during the Latenian, Roman and Migration periods). In: Czlowiek $i$ środowisko $w$ pradziejach (Man and environment in prehistorical times). Warszawa: 286-308 (in Polish).

Göransson H, 1987. Neolithic man and the forest environment around Alvastra pile dwelling. Theses and papers in North-European Archaeology, 20. Lund University Press, Lund: 90pp.

Haczewski G, Kukulak J and Bak K, 2007. Budowa geologiczna i rzeźba Bieszczadzkiego Parku Narodowego (Geology and relief of the Bieszczady National Park). Prace Monograficzne 468. Wydawnictwo Naukowe Akademii Pedagogicznej, Kraków: 155pp (in Polish).

Hejnosz W, 1960. Zagadnienie gospodarki żarowej w Polsce średniowiecznej (The problem of slush-burn economy in Mediaeval Poland). Etnografia Polska 3: 218-229 (in Polish).

Inama-Sternegg KT, 1879. Deutsche Wirtschaftsgeschichte bis zum Schluss der Karolingerperiode (German economic history until the end of the Carolingian period) 1, Lipsk: 164pp (in German).

Innes JB and Simmons I, 2000. Mid Holocene charcoal stratigraphy, fire history and palaeoecology at North Gill, North York Moors, UK. Palaeogeography, Palaeoclimatology, Palaeoecology 164(14): 151-161, DOI 10.1016/S0031-0182(00)00184-X. 
Kadrow S and Lityńska-Zając M, 1994. Analiza materiałów roślinnych ze stanowisk wczesnej epoki brązu w Iwanowicach (Analysis of plant materials from their positions Early Bronze Age in Iwanowice). Polish Botanical Studies. Guidbook 11: 31-54 (in Polish).

Kalicki T and Krąpiec M, 1991. Black oaks and Subatlantic alluvia of the Vistula in the Branice-Stryjów near Cracow. In: Evolution of the Vistula river valley during the last 15000 years, IV. Geographical Studiem, Special Issue, 6: 39-61.

Kalinowicz N and Harmata K, 2001. Fazy osadnicze w diagramach pyłkowych z doliny Bystricy (Podkarpacie) (Phase of settlement in pollen diagrams from the valley Bystrica (Subcarpathian). In: Garncarski J and Muzyczuk A, eds., Materiaty z sesji naukowej Krosno 14-15 grudnia 2000. Krosno: 223-240 (in Polish).

Kasin I, Blanck Y, Storaunet KO, Rolstad J and Ohlson M, 2013. The charcoal record in peat and mineral soil across a boreal landscape and possible linkages to climate change and recent fire history. The Holocene 23(7): 1052-1065, DOI 10.1177/0959683613479678.

Klatka T, 1968. Holoceńskie procesy rzeźbotwórcze w obszarze Gór Świętokrzyskich (Holocene relief-forming processes in the area of the Góry Świętokrzyskie). Folia Quaternaria 29. PAN. Oddz. Kraków: 89-96 (in Polish).

Klimek K, 1999. A 1000 Year Alluvial Sequence as in Indicator of Catchment/Floodplain Interaction: The Ruda Valley, SubCarpathian, Poland. In: Brown AG nad Quine TA, eds., Fluvial Processes and Environmental Change. John Wiley \& Sons: 329343.

Knox JC, 1987. Historical valley floor sedimentation in the upper Mississippi river valley. Annals of the Association of American Geographers $\quad 77(2)$ : 224-244, DOI $\quad 10.1111 / \mathrm{j} .1467-$ 8306.1987.tb00155.x.

Kosmowska-Suffczyńska D, 1983. Wpływ działalności ludzkiej na tempo przyrostu aluwiów dolinnych i zmian w krajobrazie na przykładzie doliny Czyżówki (Wyżyna Sandomierska) (Influence of human activity on the rate of valley alluvia accumulation and changes of landscape on the example of Czyżówka river valey (the Sandomierz upland). Prace i Studia Geograficzne Uniwersytetu Warszawskiego 4: 69-78 (in Polish).

Kowalska-Lewicka A, 1961. Gospodarka i trzebież żarowa w Karpatach polskich w XIX i XX wieku. Uprawa krzycy (Splash-burn economy and forest clearance in the Polish Carpathians in 20th century. Cultivation krzycy). Etnografia Polska, V, 101-116 (in Polish).

Kruk J, 1973. Studia osadnicze nad neolitem wyżyn lessowych. Ossolineum, Wrocław: 267pp (in Polish).

Kruk J, 1983. Zarys rozwoju rolnictwa neolitycznego w środowisku dorzecza górnej Wisły (Outline of Neolithic agriculture development in the environment of the upper Nida river course). In: Kozłowski JK and Kozłowski SK, eds., Człowiek i środowisko w pradziejach. Warszawa: 267-275 (in Polish).

Kryciński S, 1995. Bieszczady. Stownik Historyczno-Krajoznawczy. Cz. 1. Gmina Lutowiska (Bieszczady. Historical Dictionary Touring. Part. 1. Lutowiska Community). Warszawa - Ustrzyki Górne: 495pp (in Polish).

Kubijowicz W, 1926. Życie pasterskie w Beskidach Wschodnich (Pastoral life in the Beskidy Wschodnie). Prace Instytutu Geografii Uniwersytetu Jagiellonskiego 5. Kraków: 3-30 (in Polish).

Kukulak J, Pazdur A and Kuc T, 2002. Radiocarbon dated wood debris in floodplain deposits of the San river in the Bieszczady Mountains. Geochronometria 21: 129-136.

Kukulak J, 2004. Zapis skutków osadnictwa i gospodarki rolnej w osadach rzeki górskiej (na przykładzie aluwiów dorzecza górnego Sanu w Bieszczadach Wysokich) (Record of human settlement and agriculture in mountain river alluvium (the case of the Upper river San in the Bieszczady Wysokie). Prace Monograficzne 381. Wydawnictwa Naukowe Akademii Pedagogicznej, Kraków: 125pp (in Polish).

Kukulak J, 2005. Materiał pożarowy w aluwiach Sanu jako ślad dawnej działalności człowieka (Fire debris in alluvium of the river San as record of ancient human activity). In: Kotarba A, Krzemien K and Święchowicz J, eds., Wspólczesna ewolucja rzeźby Polski (Present evolution of relief of Poland). Uniwersytet Jagielloński, Kraków: 247-252 (in Polish).
Lamprecht K, 1878. Beträge zur Geschichte des französischen Wirtschaftslebens im elften Jahrhundert (Amounts to the history of French economic life in the eleventh century). Staats- und socialwissenschaflichche Forschungen 1(3). Lipsk: 1-87 (in German).

Latałowa M, 1994. Gospodarka mezolityczna i początki rolnictwa na obszarze polskiego Pobrzeża Bałtyku w świetle danych palinologicznych (Mesolithic economy and the beginning of agriculture in the Polish Baltic coastal zone in the light of palynological data). Polish Botanical Studies. Guidebook 11: 135-153.

Latocha A, 2007. Przemiany środowiska przyrodniczego w Sudetach Wschodnich w warunkach antropopresji (Human Impact on the Environmental Changes in the Eastern Sudetes). Studia Geograficzne 80, Wrocław: 208pp (in Polish).

Lityńska-Zając M, 1997. Węgle drzewne z osady ceramiki sznurowej w Side koło Sambora. (Charcoal from the settlement of the Corded Ware Culture at Side, near Sambor (Ukraine) Rocznik Przemyski, 33(5), Archeologia: 29-32 (in Polish).

Łowmiański H, 1953. Rolnictwo wypaleniskowe i orne (Slash-and-burn and ploughing agriculture). In: Podstawy formowania się państw stowiańskich. Warszawa: 138-178 (in Polish).

Machnik J, 1993. Polsko-słowackie i polsko-ukraińskie badania archeologiczne w Karpatach (Polish-Slovakian and Polish-Ukrainian research in the Carpathians). Prace Komisji Środkowoeuropejskiej 1: 9-21(in Polish).

Madyda-Legutko R, 1996. Zróżnicowanie kulturowe polskiej strefy beskidzkiej w okresie lateńskim i rzymskim (Cultural diversity of Polish Beskidy Zone during La Tene and Roman Periods). Rozprawy Habilitacyjne Uniwersytetu Jagiellońskiego 304, Kraków: 166pp (in Polish).

Mason SLR, 2000. Fire and Mesolithic subsistence - managing oaks for acorns in northwest Europe? Palaeogeography, Palaeoclimatology, Palaeoecology 164(1-4): 139-150, DOI 10.1016/S00310182(00)00181-4.

Moore J, 2000. Forest fire and human interaction in the early Holocene woodlands of Britain. Palaeogeography, Palaeoclimatology, Palaeoecology 164(1-4): 125-137, DOI 10.1016/S00310182(00)00180-2.

Moszyński K, 1929. Kultura ludowa Słowian (Slavic Folk Culture). I. Kultura materialna (Material culture). Kraków: 1-140 (in Polish).

Mowszowicz J, 1956. Roślinność dolnych warstw borów sosnowych na pogorzeliskach (Vegetation of the lower layers of pine woods on post-fire plots). Sylwan 3: 42-49 (in Polish).

Nichols GJ, Cripps JA, Collinson ME and Scott AC, 2000. Experiments in waterlogging and sedimentology of charcoal: results and implications. Palaeogeography, Palaeoclimatology, Palaeoecology 164(1-4): 43-56, DOI 10.1016/S0031-0182(00)00174-7.

Orzechowski S, 1991. Próba rekonstrukcji stanu zalesienia północnowschodnich obrzeży Łysogór w okresie wpływów rzymskich przyczynek do poznania środowiskowych warunków rozwoju świetokrzyskiego okregu hutniczego (An attempt at recontruction of the state of forestation on the north-east margins of the Lysogóry range in the period of Roman influence -- a contribution to the study on the conditions of development of the Świętokrzyski smelting region). Acta Archaeologica Carphatica 30: 167-186 (in Polish).

Ohlson M and Tryterud E, 2000. Interpretation of the charcoal record in forest soils: forest fires and their production and deposition of macroscopic charcoal. The Holocene 10(4): 519-525, DOI 10.1191/095968300667442551.

Pazdur MF and Michczyńska DJ, 1989. Improvement of the procedure for probabilistic calibration of radiocarbon dates. Radiocarbon 31(3): 824-832.

Pitkanen A and Huttunen P, 1999. A 1300-year forest-fire history at a site in eastern Finland based on charcoal and pollen records in laminated lake sediment. The Holocene 9(3): 311-320, DOI $10.1191 / 095968399667329540$.

Ralska-Jasiewiczowa M, 1980. Late Glacial and Holocene of the Bieszczady Mts (polish Eastern Carpathians). PWN, Warszawa Kraków: 199pp.

Ralska-Jasiewiczowa M, 1989. Type region: The Bieszczady Mts. Acto Paleobotanica 29: 31-35. 
Rehman A, 1895. Ziemie dawnej Polski. I. Karpaty (The lands of the former Polish. I. Carpathians). Lwów: 473-509 (in Polish).

Reimer PJ, Bard E, Bayliss A, Beck JW, Blackwell PG, Bronk Ramsey C, Buck CE, Cheng H, Edwards RL, Friedrich M, Grootes PM, Guilderson TP, Haflidason H, Hajdas I, Hatté C, Heaton TJ, Hoffmann DL, Hogg AG, Hughen KA, Kaiser KF, Kromer B, Manning SW, Niu M, Reimer RW, Richards DA, Scott EM, Southon JR, Staff RA, Turney CSM and van der Plicht J, 2013. IntCal13 and Marine13 radiocarbon age calibration curves 0 50,000 years cal BP. Radiocarbon 55(4): 1869-1887.

Reinfuss R, 1939. Ze studiów nad kulturą materialną Bojków (From the studies on the material culture of the Bojko). Roczniki Ziem Górskich: 31-263 (in Polish).

Rygiel Z, 1987. Zarys gospodarki leśnej i przemysłu drzewnego w okresie międzywojennym i w latach okupacji w Bieszczadach Wysokich (An outline of forest economy and wood industry in the Bieszczady Mountains in the period between the world wars and during the [German] occupation). Sylwan 131(6): 37-53 (in Polish).

Rygiel Z, 1998. Świerk bieszczadzki "tarnawski" w przeszłości i jego stan aktualny (Bieszczady Spruce "tarnawski" in past and current state). Sylwan 142(10): 39-48 (in Polish).

Schmidt MWI and Noack AG, 2000. Black carbon in soils and sediments: Analysis, distribution, implications, and current challenges. Global Biogeochemical Cycles 14(3): 777-793, DOI 10.1029/1999GB001208.

Schramm W, 1956. Na wschód od Osławy (East of the Osława river). Wierchy 25: 101-124 (in Polish).

Schramm W, 1958. Lasy i zwierzyna Gór Sanockich (Forests and deer of Sanockie Mountains). PWN: 115 (in Polish).

Schweingruber FH, 1978. Mikroskopische Holzanatomie (Wood anatomical structure using microscope). Schweizerischen Nationalfonds zur Förderung der wissenschaftlichen Forschung unterstützte Untersuchung. Zürich: 226pp (in German).

Scott AC, 2010. Charcoal recogniton, taphonomy and uses in palaeoenvironmental analysis. Palaeogeography, Palaeoclimatology, Palaeoecology 291(1-2): 11-39, DOI 10.1016/j.palaeo.2009.12.012.

Simmons IG, 1978. Człowiek a środowisko geograficzne w Wielkiej Brytanii (Mesolithic man and environment in Britain) Przeglad Geograficzny 50(3): 371-388 (in Polish).

Simmons IG and Innes JB, 1996. Prehistoric charcoal in peat profiles at North Gill, North Yorkshire Moors, England. Journal Archaeological Science 23(2): 193-197, DOI 10.1006/jasc.1996.0017.

Smart LT and Hoffman ES, 1988. Environmental interpretation of archaeological charcoal. In: Hastorf CA and Popper VS, eds., Current Paleoethnobotany. Analytical Methods and Cultural Interpretations of Archaeological Plant Remains. The University of Chicago Press, Chicago, pp. 167-205.

Starkel L, 1987. Man as a cause of sedimentologic changes in the Holocene: anthropogenicsedimentological changes during the Holocene. Striae 26: 5-12.

Stepnik T, 2007. Identyfikacja taksonomiczna węgli drzewnych (Taxonomic indentification of charcoal). In: Studia i materiaty do badań nad późnym neolitem Wysoczyzny Kujawskiej. Opatowice, Wzgórze Prokopiaka, II: 249-255 (in Polish).

Stępnik T, 2010. Skład taksonomiczny węgli drzewnych ze stanowiska 12 w Wilanowie, pow. Grodzisk Wlkp. - sezony 2006-2007 (Taxonomic composition of charcoal from site 12 at Wilanów, county Grodzisk Wlkp. - seasons 2006-2007). Slavia Antiqua 51: 212-215 (in Polish)

Strzelecki H, 1900. Lasy i leśnictwo w Galicji w XIX w. (Forests and forestry in Galicia in 19th c.). Sylwan 18(1-13): 44-51 (in Polish).

Szewczuk J, 1939. Kronika klęsk elementarnych w Galicji w latach 1772-1848 (Chronicle of natural disasters in Galicia in years 1772-1848). Roczniki Dziejów Społecznych i Gospodarczych 35. Lwów: 334pp (in Polish).

Szczepanek K, 1987. Late Glacial and Holocene pollen diagrams from
Jasiel in the Low Beskid Mts (The Carpathians). Acta Paleobotanica 27(1): 9-26.

Ślączka A, Bober L, Chowaniec J, Cieszkowski M, Gierat-Nawrocka D and Zuchiewicz W, 1991. Objaśnienia do Szczegótowej Mapy Geologicznej Polski. Ark. Jaśliska. (Explanations to the Detailed Geological Map of Poland 1:50 000. Sheet Jaśliska (1056). Wyd. PIG. Warszawa: 1-97 (in Polish).

Śląski K, 1965. Lasy a osadnictwo (Forests and settlement). In: Dzieje lasów, leśnictwa i drzewnictwa w Polsce ( The history of forests, forestry and the wood industry in Poland). PWRiL. Warszawa: 4360 (in Polish).

Teisseyre AK, 1989. Mady dolin sudeckich. Czesść III: Subarealnie i subakwalnie deponowane osady pozakorytowe w świetle eksperymentu terenowego (1977-1979). (Recent overbank deposits of the Sudetic valley, SW Poland. Part. III: Subaerially and subaqueously deposited overbank sediments in the light of field experiment (1977-1979). Geologica Sudetica 23(2): 1-81 (in Polish).

Tinner W, Conedera M, Ammann B, Gaggeler HW, Gedye S, Jones R and Sagesser B, 1998. Pollen and charcoal in lake sediments compared with historically documented forest fires in southern Switzerland since $\mathrm{AD}$ 1920. The Holocene 8(1): 31-42, DOI $10.1191 / 095968398667205430$.

Tipping R and Milburn P, 2000. The mid-Holocene charcoal fall in southern Scotland - temporal and spatial varability. Palaeogeography, Palaeoclimatology, Palaeoecology 164(1-4): 177-193, DOI 10.1016/S0031-0182(00)00185-1.

Trietiakow PN, 1948. Selskoje chozjajstwo i promysły. Istoria kultury driewniej Rosji (Agriculture and industries. Cultural history of ancient Russia). I. Leningrad; 1-55 (in Russian).

Tokarz W, 1909. Galicja w początkach ery józefińskiej w świetle ankiety urzędowej z roku 1783 (Galicia at the beginning of the Josephine era in the light of an official survey from year 1783). Akad. Umiej. w Krakowie: 1-440 (in Polish).

Tunia K, 1986. Z problematyki środowiskowych uwarunkowań gospodarki pasterskiej na terenie górskiej strefy polskich Karpat Zachodnich (On the environmental conditions of pastorial economy in the mountain zone of the Polish Western Carpathians). Acta Archaeologica Carpathica 25: 219-230 (in Polish).

Vanniere B, Bossuet G and Gauthier E, 2000. Mineral magnetic susceptibility and palynological evidences of human impact and fluvial process in the lower Doubs valley (Jura, France) between 1th-8th century AD. Comptes Rendus de l'Academie des Sciences, Series IIA. Earth and Planetary Science 331(3): 203-210.

Walanus A and Goslar T, 2009. Datowanie radioweglowe (Radiocarbon Dating). Wyd. AGH: 148pp (in Polish).

Wasylikowa K, 1983. Antropogeniczne zmiany roślinności w holocenie (Anthropogenic changes in vegetation during the Holocene). In: Kozłowski JK and Kozłowski SK, eds., Człowiek $i$ środowisko w pradziejach. PWN, Warszawa: 53-79 (in Polish).

Wasylikowa K, Gluza I, Lityńska-Zając M and Tomczyńska Z, 1992. Charcoals from Neolithic settlements in the loess area of southcentral Poland. Bulletin de la Société botanique de France 139. Actualités botaniques 2-4: 373-382.

Wiślański T, 1979. Kształtowanie się miejscowych kultur rolniczohodowlanych. Plemiona kultury pucharów lejkowatych (Development of local farming-herding cultures. Tribes of the funnel beaker culture). In: Prahistoria ziem polskich, II: Neolit. Wrocław: 165260 (in Polish)

Wójcicki K and Marynowski L, 2011. Zawartość węgla organicznego w osadach dolinnych jako wskaźnik denudacji holoceńskiej w dorzeczu górnej Odry (Organic-carbon content as an indicator of Holocene denudation in the Upper Odra river basin). Przeglad Geograficzny 83(1): 5-26 (in Polish).

Zarzycki K, 1963. Lasy Bieszczadów Zachodnich (Forests of the Bieszczady Zachodnie). Acta Agraria Et Silvestria 3: 122pp (in Polish).

Żaki A, 1955. Poczatki osadnictwa w Karpatach polskich (Beginnings of settlement in the Polish Carpathians). Wierchy 24: 99-116 (in Polish). 